\title{
Perbandingan Algoritma Machine Learning dalam Menilai Sebuah Lokasi Toko Ritel
}

\author{
http://dx.doi.org/10.28932/jutisi.v7i1.3182 \\ Riwayat Artikel \\ Received: 7 Desember 2020 | Final Revision: 20 Februari 2021 | Accepted: 1 Maret 2021 \\ Kristiawan $^{\# 1}$, Andreas Widjaja ${ }^{\varpi * 2}$ \\ Magister Ilmu Komputer, Universitas Kristen \\ Jl. Surya Sumantri No. 65, Sukawarna, Kec. Sukajadi, Kota Bandung, Jawa Barat 40164 \\ ${ }^{1}$ kristiawan.indi@gmail.com \\ ªndreas.widjajalit.maranatha.edu
}

\begin{abstract}
The application of machine learning technology in various industrial fields is currently developing rapidly, including in the retail industry. This study aims to find the most accurate algorithmic model so that it can be used to help retailers choose a store location more precisely. By using several methods such as Pearson Correlation, Chi-Square Features, Recursive Feature Elimination and Tree-based to select features (predictive variables). These features are then used to train and build models using 6 different classification algorithms such as Logistic Regression, K Nearest Neighbour (KNN), Decision Tree, Random Forest, Support Vector Machine (SVM) and Neural Network to classify whether a location is recommended or not as a new store location.
\end{abstract}

Keywords- Application of Machine Learning, Pearson Correlation, Random Forest, Neural Network, Logistic Regression.

\section{Pendahuluan}

Industri retail adalah industry yang sangat menarik bagi banyak pembisnis. Menurut majalah Forbes dari daftar 10 keluarga terkaya di Amerika Serikat, yang menduduki peringkat nomor satu adalah keluarga Waltons yang merupakan pengusaha jaringan retail Walmart [1]. Selain mendatangkan keuntungan yang besar industri retail adalah industry yang paling tahan banting, di saat perusahaan industri lain harus mengalami kerugian dan harus menutup bisnisnya, perusahaan retail tetap bertahan, contoh nyata saat pandemi covid 19, di saat semua perusahaan harus menutup kantor dan tempat usahanya, toko-toko retail tetap buka dan menjalankan bisnisnya sekalipun dengan berbagai macam aturan dan batasan.

Maka dari itu tidak heran banyak pengusaha-pengusaha besar yang ingin berbisnis di bisnis retail, tetapi industry retail bukan bisnis yang mudah, khususnya untuk pemainpemain baru. Industry retail memiliki entry barrier yang tinggi karena harus menghadapi peritel-peritel lama yang sudah berpengalaman dan juga karena sifat bisnis retail yang padat karya dan memiliki margin yang rendah membuat banyak pengusaha harus benar-benar efektif dan efisien dan tidak boleh salah dalam membuat keputusan.

Salah satu faktor utama yang mempengaruhi keberhasilan bisnis retail adalah penentuan lokasi, salah memilih lokasi bisa berakibat fatal, selain membuat toko tidak berkembang karena marketnya tidak tumbuh juga bisa menyebabkan toko tersebut tutup karena merugi.

Banyak cara dalam memilih sebuah lokasi dari yang menggunakan intuisi, menggunakan metode statistik sederhana sampai menggunakan sistem pendukung keputusan seperti nä̈ve bayes [2] [3]. Penelitian ini bermaksud untuk memberikan cara lain yang lebih akurat dalam menentukan lokasi toko ritel dengan menggunkan algoritma machine learning.

Rumusan masalah dalam penelitian ini adalah bagaimana mendapatkan algoritma machine learning yang menghasilkan model terbaik, yang dapat memberikan rekomendasi apakah sebuah lokasi tepat untuk dijadikan toko baru atau tidak?

Penelitian ini akan dibatasi pada algoritma machine learning dengan pendekatan supervised learning. Pendekatan supervised learning adalah salah satu cabang besar dari machine learning yang membuat sebuah fungsi atau model dari data pelatihan yang sudah diberi label. Data-data pelatihan tersebut bentuknya berupa pasangan input, output (label). Jenis algoritma yang digunakan adalah Classification Algorithm dengan menggunakan metode binary classification untuk membuat sebuah fungsi atau model yang dapat melakukan klasifikasi apakah sebuat lokasi direkomendasi atau tidak untuk dijadikan toko baru.

Pembuatan model menggunakan enam macam algoritma klasifikasi yang berbeda, yang nantinya setiap model yang dihasilkan oleh masing-masing algoritma tersebut akan dibandingkan. Adapun algoritma klasifikasi yang akan dibandingkan adalah Logistic Regression, Lasso, Decision Tree, Random Forest, Support Vector Machine dan Neural Network. 


\section{KAJIAN LITERATUR}

Dalam penelitian ini, menggunakan literatur-literatur yang terkait seputar sub bagian machine learning yaitu Supervised, Unsupervised Learning, Algoritma klasifikasi seperti Logistic Regression, K-Nearest Neighbor (KNN), Decision Tree, Random Forest, Support Vector Machine (SVM) dan Neural Network. Selain itu ada beberapa metode Features Selection seperti Lasso, Pearson Correlation dan juga ada tentang Cross Validation untuk mencegah Overfitting serta terakhir metode untuk melakukan evaluasi model menggunakan Confusion Matrix dan kurva ROC dan AUC.

\section{A. Supervised dan Unsupervised Learning}

Supervised Learning adalah Teknik melatih mesin menggunakan data yang diberi label [4]. Maksud dari pembelajaran yang diawasi adalah data label atau target ikut berperan sebagai 'supervisor' atau 'guru' yang mengawasi proses pembelajaran dalam mencapai tingkat akurasi atau presisi tertentu. Artinya beberapa data sudah ditandai dengan jawaban yang benar dan mesin belajar untuk membuat sebuah model yang akan menghasilkan hasil yang benar atau mendekati bila diberikan data baru. Misalkan kita ingin memprediksi harga sebuah rumah maka dengan memasukkan variabel input luas rumah, jumlah kamar dan variabel harga sebagai variable ouput yang merupakan label maka kita bisa membuat sebuah model yang bisa memprediksi harga sebuah rumah. Contoh algoritma yang termasuk Supervised Learning adalah Regresi dan klasifikasi lihat Gambar 1.

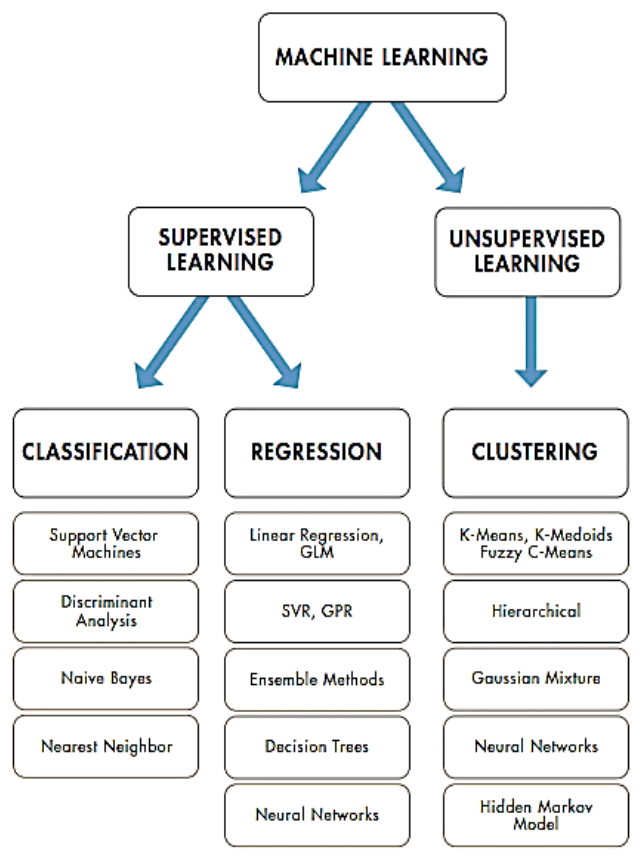

Gambar 1. Supervised and Unsupervised learning [4]
Unsupervised machine learning adalah teknik pembelajaran mesin, di mana machine tidak perlu diawasi diberi jawaban yang benar. Sebaliknya, mesin diijinkan bekerja sendiri untuk menemukan informasi. Hal Ini terutama berkaitan dengan data tidak berlabel. Misalkan kita ingin mengelompokkan rumah berdasarkan jumlah kamar dan luas rumah, maka dengan memberikan data rumah dengan variabel jumlah kamar dan luas rumah mesin akan membuat model yang bisa mengelompokan rumah menjadi beberapa kelompok berdasarkan kedua variabel tersebut, sehingga jika nanti ada data baru maka mesin bisa menebak bahwa rumah tersebut akan termasuk kelompok yang mana. Contoh algoritma yang termasuk Unsupervised Learning adalah: Clustering, Association dan Dimensionality Reduction [2].

\section{B. Logistic Regression}

Logistic Regression atau Regresi logistik adalah kasus khusus dari regresi linier di mana variabel target bersifat kategorikal. Regresi logistic dipakai untuk memprediksi kelas biner 0 atau 1 [4]. Variabel hasil atau target bersifat dikotomis. Dikotomis berarti hanya ada dua kemungkinan, ya dan tidak, dengan hanya dua kemungkinan, regresi logistik, dapat digunakan untuk mendeteksi kanker, email spam atau bukan spam [4].

\section{K-Nearest Neighbor $(K N N)$}

Secara Sederhana K-nearest neighbor atau KNN adalah algoritma yang berfungsi untuk melakukan klasifikasi suatu data berdasarkan data pembelajaran (train data sets), yang diambil dari $k$ tetangga terdekatnya (nearest neighbors). Dengan $k$ merupakan banyaknya tetangga terdekat. Hasil klasifikasinya berdasarkan mayoritas kedekatan jarak dari tetangga terdekatnya [5]

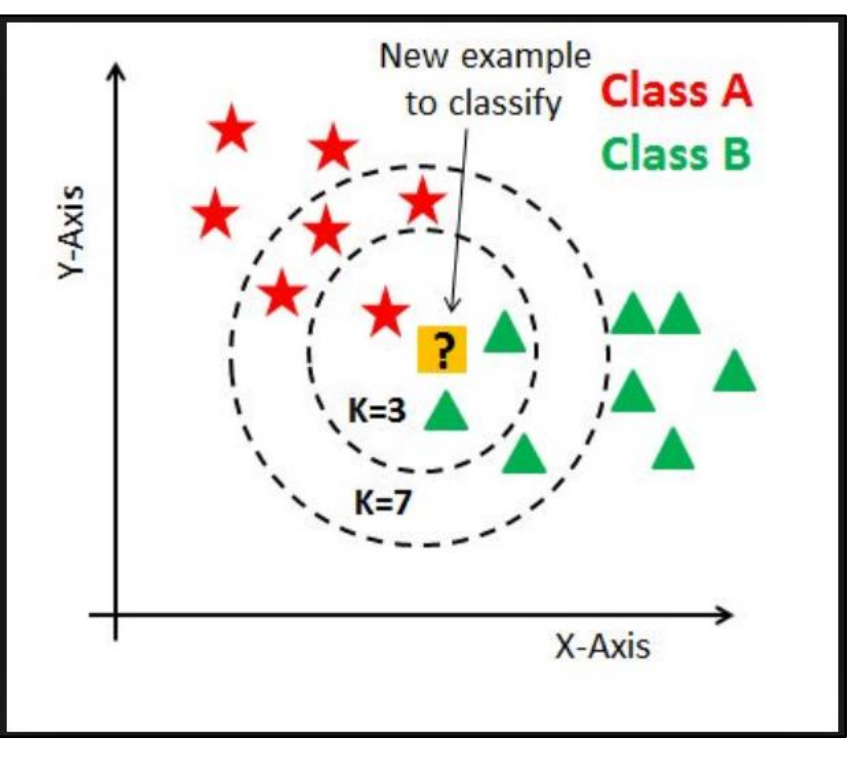

Gambar 2. K-Nearest Neighbor [5] 


\section{Decision Tree}

Decision Tress atau Pohon Keputusan adalah jenis algoritma untuk pembelajaran mesin pemodelan prediktif. Representasi untuk model Decision Trees adalah pohon biner.

Setiap node mewakili satu variabel input $(x)$ dan cabangnya merepresentasikan nilai dari variabel input tersebut, sedangkan simpulnya merepresentasikan variable output $(y)$ atau kelas. Node teratas dari decision tree ini disebut root. Dinamakan pohon keputusan karena aturan yang terbentuk mirip dengan bentuk pohon [6].

\section{E. Random Forest}

Random Forest adalah salah satu algoritma pembelajaran mesin yang paling populer dan termasuk salah satu yang paling kuat. Random Forests adalah perbaikan dari pohon keputusan. Disebut Random Forest atau hutan "acak"? Karena hutan pohon keputusan yang dibuat secara acak. Setiap node di pohon keputusan bekerja pada subset fitur acak (bukan greedy algoritma) untuk menghitung output. Random Forest kemudian menggabungkan keluaran dari pohon keputusan individu untuk menghasilkan keluaran akhir [6].

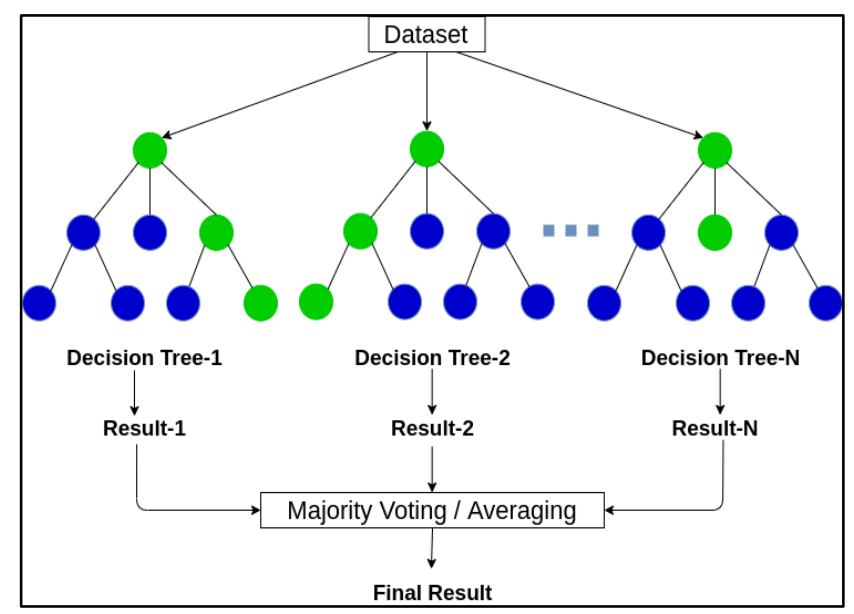

Gambar 3. Random Forest [6]

\section{F. Support Vector Machine (SVM)}

Support Vector Machine (SVM) merupakan salah satu metode dalam supervised learning yang biasanya digunakan untuk klasifikasi (seperti Support Vector Classification) dan regresi (Support Vector Regression) baik untuk data linear maupun nonlinear. SVM melakukan klasifikasi dengan cara memilih batas keputusan yang memaksimalkan (maximum Margin Classifier) jarak dari titik data terdekat dari semua kelas. Batas keputusan yang dibuat oleh SVM disebut pengklasifikasi margin maksimum(maximal margin classifier) atau bidang hiper (Hyperplane) margin maksimum [7].

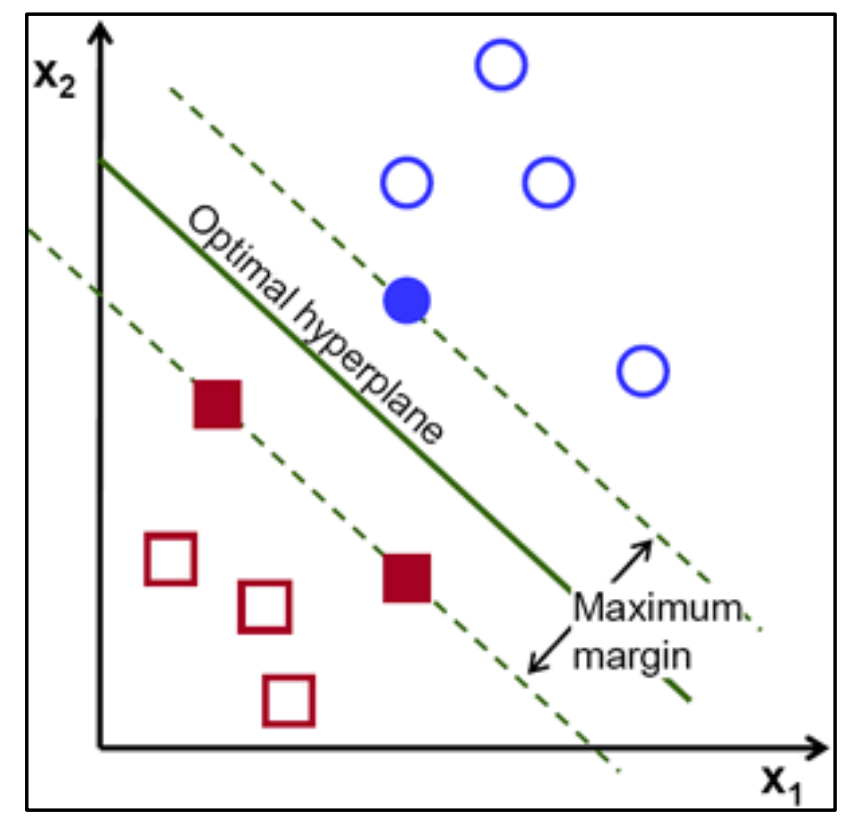

Gambar 4. SVM Maximum Margin Classifier [7]

\section{G. Neural Network}

Neural Network atau Jaringan Saraf adalah pembentuk atau tulang punggung dari Algoritma Deep Learning. Deep Learning adalah bagian sub bagian dari machine learning dan machine learning adalah sub bagian dari bidang Artificial Intelligent. Neural network (jaringan saraf) bekerja dengan cara meniru kerja neuron (saraf) dalam otak manusia.

Secara sederhana neural network dibentuk dari dari 3 macam layer, input layer berfungsi menerima masukkan, output layer berfungsi memprediksi hasil akhir keluaran dan di tengah-tengahnya terdapat hidden layer yang berfungsi melakukan sebagian besar komputasi yang dibutuhkan oleh jaringan [8].

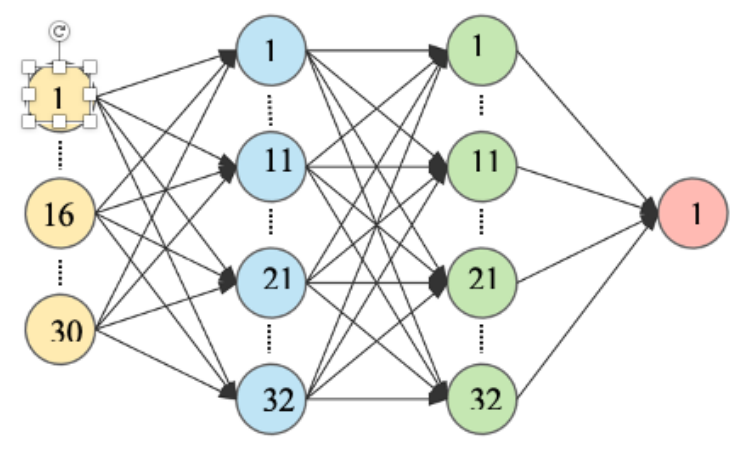

input layer hidden layer $1 \quad$ hidden layer $2 \quad$ output layer 


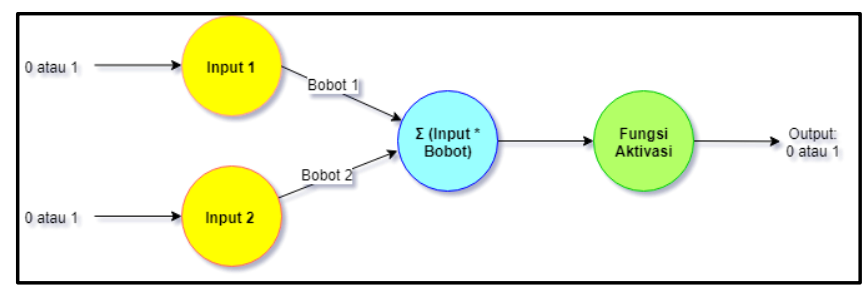

Gambar 6. Neural Network sederhana

\section{H. Features Selection}

Data yang digunakan untuk melatih model pembelajaran mesin memiliki pengaruh besar pada performa yang dapat dicapai. features yang tidak relevan atau sebagian relevan dapat berdampak negatif pada performa model.

Ada tiga manfaat melakukan pemilihan features sebelum membuat model:

- Mengurangi Overfitting (kondisi di mana bekerja dengan sangat baik terhadap data training tetapi berkinerja buruk terhadap data real): lebih sedikit data yang berlebihan berarti lebih sedikit peluang untuk membuat keputusan berdasarkan bias.

- Meningkatkan Akurasi: lebih sedikit data yang tidak relevan berarti akurasi pemodelan meningkat.

- Mengurangi waktu pelatihan: Lebih sedikit data berarti algoritma berlatih lebih cepat.

Beberapa cara atau metode untuk mengaplikasikan features selection, di antaranya adalah:

- Filter Method melakukan filtering pada dataset dan mengambil hanya bagian data yang mengandung semua fitur yang relevan (Contoh: Matrix Correlation dengan menggunakan metode Pearson ) [9].

- Wrapper Method mengikuti cara seperti metode filter tetapi memakai machine learning model sebagai kriteria evaluasinya (contoh. Forward/Backward /Bidirectional/ Recursive Feature Elimination) [9]. Memasukkan beberapa fitur ke model machine learning, mengevaluasi kinerjanya dan kemudian memutuskan apakah menambah atau menghapus fitur untuk meningkatkan akurasi. Metode ini bisa lebih akurat daripada pemfilteran tetapi lebih banyak melakukan proses komputasi.

- Embedded Method metodenya seperti metode wrapper, Embedded Method juga menggunakan machine learning model. Perbedaannya pada wrapper fitur diintegrasikan ke model sedangkan pada embedded methode fiturnya di embedded, dengan melakukan proses iterasi pelatihan model machine learning dan kemudian membuat peringkat tingkat kepentingan dari setiap fitur berdasarkan berapa banyak masing-masing fitur berkontribusi pada pelatihan model machine learning (mis. regresi LASSO) [9].

\section{Cross Validation}

Cross Validation digunakan untuk mencegah overfitting, Ada berbagai jenis Teknik Cross Validation (Validasi Silang) tetapi konsep keseluruhannya tetap sama, yaitu:

- Mempartisi data menjadi beberapa subset

- Menyimpan satu set pada satu waktu dan melatih model pada set yang tersisa

- Uji model pada data yang tadi disimpan

Contoh metode Cross Validation yang umumnya digunakan adalah Fold Cross Validation [10].

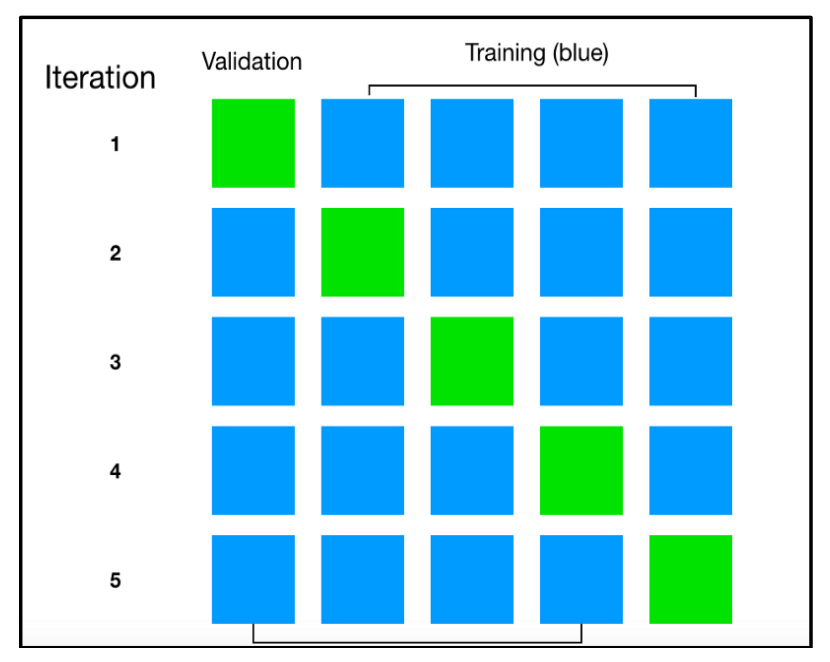

Gambar 7. 5-Fold Cross Validation [10]

\section{METODOLOGI PENELITIAN}

A. Hipotesis-Hipotesis

Penelitian ini didasarkan pada hipotesis-hipotesis berikut ini:

- Tidak semua features penting atau memiliki peranan dalam pembuatan model, ada features yang perannya tidak penting sehingga boleh dihilangkan.

- Setiap algoritma memiliki karakteristik karakteristik yang berbeda-beda tergantung dari jenis atau type dari datanya sehingga setiap algoritma akan memiliki tingkat akurasi yang berbeda-beda juga.

\section{B. Tahapan Penelitian}

Proses penelitian tesis ini dapat dilihat pada Langkahlangkah berikut ini:

1. Preprocessing data

2. Seleksi fitur

3. Membuat Model

4. Evaluasi

5. Membandingkan model 
Langkah pertama dengan preprocesssing data:

\section{a) Proses Encoding}

Encoding adalah salah satu tahap preprocessing data adalah proses merubah tipe data kategori ke numerik sebelum diproses dengan algoritma machine learning. Dalam mengerjakan projek data science ataupun machine learning, akan sangat mungkin menemukan satu atau beberapa fitur yang bertipe kategori, misalnya salah satu kategori dalam tesis ini adalah kebiasaan_belanja 'Harian, 'Mingguan', 'Bulanan'. Algoritma machne learning klasifikasi tidak dapat memproses data bertipe kategori sehingga data harus diubah menjadi berbentuk bilangan. Proses ini perubahan tersebut disebut dengan encoding. Proses encoding yang dilakukan menggunakan metode OneHot encoding. Metode ini merepresentasikan data bertipe kategori sebagai vektor biner yang bernilai integer, 0 dan 1, di mana semua elemen akan bernilai 0 kecuali elemen yang memiliki nilai kategori nilainya 1 . Fungsi yang digunakan adalah fungsi pd.get_dummies yang berfungsi mengubah data kategori menjadi vector biner. Salah satu contoh data yang dikonversi adalah: data kebiasaan belanja seperti pada tabel 1:

TABEL I

KeBIASAAN BELANJA

\begin{tabular}{|l|}
\hline kebiasaan_belanja \\
\hline Mingguan \\
\hline Harian \\
\hline Mingguan \\
\hline Harian \\
\hline Harian \\
\hline Mingguan \\
\hline Harian \\
\hline Harian \\
\hline Harian \\
\hline Harian \\
\hline Bulanan \\
\hline
\end{tabular}

Dengan menggunakan fungsi pd.get_dummies dari library panda, Tabel 1 diencode.
TABEL II

Tabel KebiasaAn Belanja Yang Sudah Diencode

\begin{tabular}{|rrrrr|}
\hline & kebiasaan_belanja & Bulanan & Harian & Mingguan \\
\hline 0 & Mingguan & 0 & 0 & 1 \\
1 & Harian & 0 & 1 & 0 \\
2 & Mingguan & 0 & 0 & 1 \\
3 & Harian & 0 & 1 & 0 \\
4 & Harian & 0 & 1 & 0 \\
$\ldots$ & $\ldots$ & $\ldots$ & $\ldots$ & $\ldots$ \\
252 & Harian & 0 & 1 & 0 \\
253 & Mingguan & 0 & 0 & 1 \\
254 & Mingguan & 0 & 0 & 1 \\
255 & Harian & 0 & 1 & 0 \\
256 & Harian & 0 & 1 & 0 \\
257 rows $\times 4$ columns & & & \\
\hline
\end{tabular}

Berikut adalah tampilan potongan dataset yang sudah melalui proses encoding

TABEL III

Potongan DATASET YANG SUdAh DiENCODE

\begin{tabular}{rrrrrrrrrrrr} 
& Bis & Angkot & OJek & roda2 & roda4 & pejalan_kaki & BCA & BNI & Ibadah & pasar & $\ldots$ \\
\hline 0 & 0 & 1 & 0 & 3012 & 1452 & 65 & 1 & 0 & 0 & 0 & $\ldots$ \\
1 & 0 & 0 & 1 & 882 & 108 & 135 & 1 & 0 & 0 & 0 & $\ldots$ \\
2 & 0 & 0 & 0 & 20 & 10 & 15 & 1 & 0 & 0 & 0 & $\ldots$ \\
3 & 1 & 0 & 0 & 20 & 120 & 30 & 1 & 1 & 1 & 0 & $\ldots$ \\
4 & 0 & 1 & 1 & 1908 & 419 & 64 & 0 & 0 & 0 & 1 & $\ldots$ \\
$\ldots$ & $\ldots$ & $\ldots$ & $\ldots$ & $\ldots$ & $\ldots$ & $\ldots$ & $\ldots$ & $\ldots$ & $\ldots$ & $\ldots$ & $\ldots$ \\
249 & 0 & 1 & 1 & 1322 & 495 & 75 & 0 & 0 & 0 & 1 & $\ldots$ \\
250 & 0 & 1 & 1 & 3600 & 720 & 300 & 1 & 0 & 1 & 0 & $\ldots$ \\
251 & 1 & 1 & 1 & 2700 & 1300 & 360 & 1 & 0 & 0 & 1 & $\ldots$ \\
252 & 0 & 1 & 0 & 624 & 600 & 24 & 0 & 0 & 1 & 0 & $\ldots$ \\
253 & 0 & 0 & 0 & 100 & 200 & 5 & 1 & 0 & 0 & 0 & $\ldots$
\end{tabular}

254 rows $\times 31$ columns

\section{b) Pengecekan Missing Data}

Proses ini untuk memastikan tidak ada data yang invalid atau kosong. Menset features (variable praduga) dan label (variabel target). Dengan menggunakan fungsi is. null (), program akan melakukan pengecekan apakah ada kolom-kolom yang datanya tidak lengkap. Hasil pengecekannya seperti di bawah ini 
Tabel 1 Hasil pengecekan dengan fungsi is.null()

jml_lantai
Bis
Angkot
Ojek
lainnya
lebar_besar6m
lebar_kecil3m
lebar_sedang3-6m
jalur_cepat
jalur_lambat
Length: 63, dtype: int64.

Terlihat semua data tidak ada yang kosong atau invalid.

\section{c) Feature Scaling}

Beberapa algoritma machine learning memerlukan tambahan preprocessing data sebelum melakukan proses training model. Algoritma MACHINE LEARNING seperti KNN dan SVM adalah algoritma berbasis jarak yang sangat dipengaruhi oleh besar dan nilai dari fitur-fiturnya. Hal ini terjadi karena di balik layar algoritma-algoritma tersebut menggunakan jarak antar titik data untuk menentukan kesamaannya. Oleh karena itu sebelum mentraining data, data harus di features scaling dulu agar semua fiturnya memiliki berkontribusi sama pada hasil dan tidak menjadi bias terhadap satu fitur saja.

\section{d) Standarization}

Algoritma lain seperti neural network, membutuhkan perlakuan yang berbeda, neural network membutuhkan proses standarisasi data sebelum melakukan training model. Alasan pertama untuk menghilangkan pengaruh satu faktor di atas faktor lainnya (yaitu untuk memberikan fitur peluang yang sama), alasan kedua metode gradient descent untuk mekanisime backpropagasi, normalization akan mempercepat pembelajaran dan mengarah ke konvergensi yang lebih cepat dibandingkan dengan data yang tidak distandarisasi.

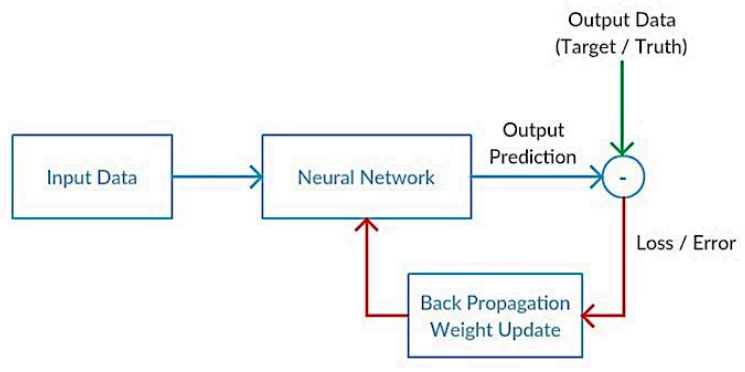

Gambar 9 Back Propagation

$$
X_{\text {Stand }}=\frac{X-\operatorname{Mean}(x)}{\text { standard deviation }(x)}
$$

Gambar 8. Standardization equation

Langkah kedua setelah preprocessing data adalah melakukan seleksi fitur. Seleksi fitur dilakukan dengan menggunakan berbagai macam metode seperti metode filtering dengan Pearson Correlation, metode Recursive Feature Elimination dengan random forest dan, metode wrapper dengan Lasso [9]. Berikut adalah salah satu contoh seleksi fitur dengan menggunakan Pearson Correlation dan menampilkannya dengan library Seaborn.

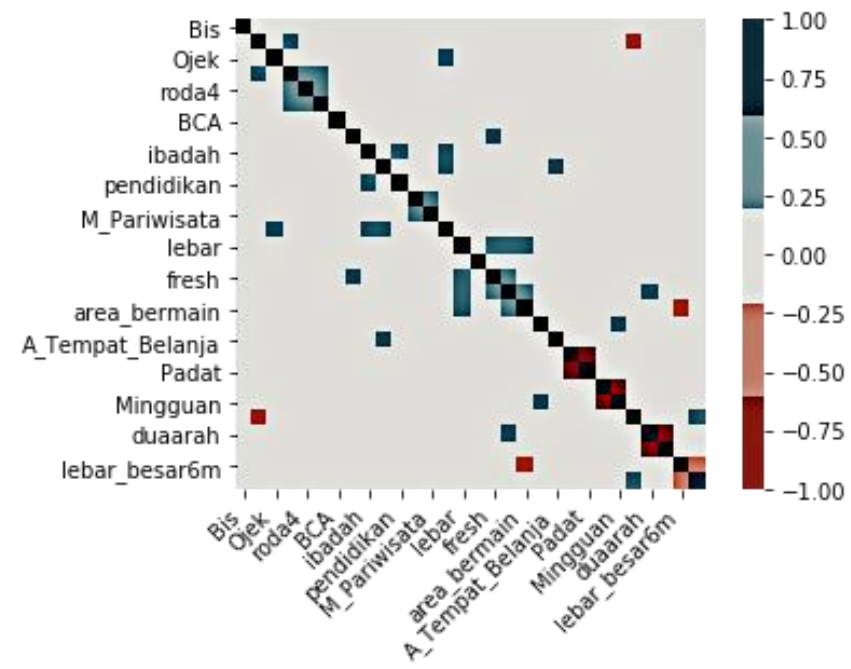

Gambar 9. Matrix Correlation (Pearson Correlation)

Dari Gambar Matrix Correlation ada beberapa pasangan features yang memiliki nilai korelasi yang tinggi, yaitu :

$\begin{array}{lll}\text { Kurang_Padat } & \text { Padat } & -1.000000 \\ \text { Padat } & \text { Kurang_Padat } & -1.000000 \\ \text { duaarah } & \text { satuarah } & -0.802657 \\ \text { satuarah } & \text { duaarah } & -0.802657\end{array}$

Features yang memiliki pasangan tinggi bisa didrop, dalam kasus ini features kurang padat dan satu arah bisa didrop karena sudah bisa diwakilkan oleh feature padat dan dua arah.

Langkah ketiga membuat model. Setelah data set siap saatnya untuk membuat model dengan menggunakan $k$-fold 10 cross validation. Pembuatan model dilakukan dengan menggunakan 6 macam algoritma seperti: Logistic Regression, K-Nearest Neighbor (KNN), Decision Tree, Random Forest, Support Vector Machine (SVM) dan Neural Network. 
Langkah keempat setelah model dibuat maka dilakukan proses evaluasi untuk setiap model. Evaluasi dilakukan dengan menggunakan 2 alat ukur:

1. Confusion Matrix

2. Kurva ROC dan AUC

confusion matrix akan menghitung nilai accuracy, sensitivity, precession, recall dan F1 score. Kurva ROC dan AUC akan mevisualisasikannya.

Langkah kelima membandingkan hasil evaluasi dari satu model dengan model lainnya dan memilih algoritma yang menghasilkan model yang terbaik.

\section{IV.Evaluasi Model Hasil DaN PEMBaHASAN MODEL}

Dalam melakukan evaluasi model digunakan dua macam metode yaitu confusion matrix dan kurva ROC dan AUC.

\section{A. Confusion Matrix}

Confusion Matrix adalah tabel yang sering digunakan untuk mendeskripsikan performa model machine learning. Confusion Matrix merepresentasikan prediksi dan kondisi sebenarnya(aktual) dari data yang dihasilkan oleh algoritma machine learning khususnya model klasifikasi.[3]

Ada 4 kondisi dalam Confusion Matrix:

- True Positive (TP) prediksi positive, real positive

- $\quad$ True Negative (TN) prediksi negative, real negative

- False Positive (FP) prediksi positive, real negative

- False Negative (FN) prediksi negative, real positive

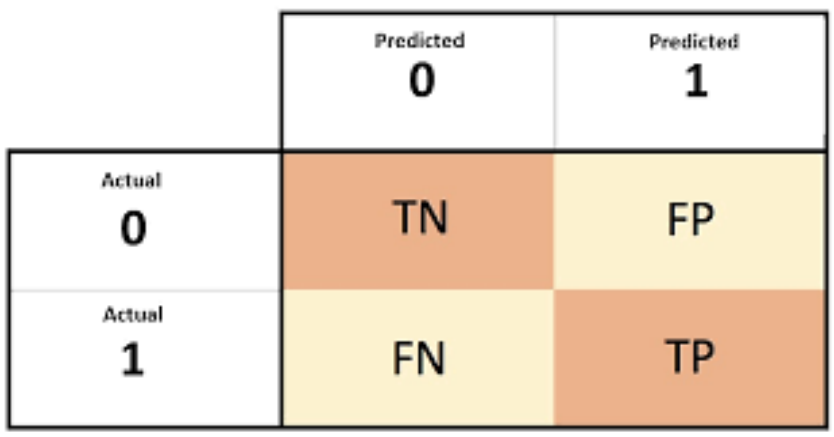

Gambar 9. Confusion Matrix

Dari hasil confusion matrix didapatkan Tabel performance sebagai berikut (Tabel 4). Berdasarkan Confusion Matrix, kita bisa menentukan Accuracy, Precision, Recall, Specificity dan F1 Score [11].
TABEL IV

Performance CONFUSION MATRIX DARI SETIAP MOdEL

\begin{tabular}{|l|l|l|l|l|l|}
\hline Algoritma & Accuracy & $\begin{array}{l}\text { Sensitivity } \\
\text { (Recall) }\end{array}$ & Specificity & Precision & $\begin{array}{l}\text { F_1 } \\
\text { Score }\end{array}$ \\
\hline $\begin{array}{l}\text { Logistic } \\
\text { Regression }\end{array}$ & $90 \%$ & $97 \%$ & $21 \%$ & $92 \%$ & $95 \%$ \\
\hline $\begin{array}{l}\text { K Nearest } \\
\text { Neighbor } \\
\text { (KNN) }\end{array}$ & $90 \%$ & $99 \%$ & 0.0 & $90 \%$ & $95 \%$ \\
\hline $\begin{array}{l}\text { Decision } \\
\text { Tree }\end{array}$ & $84 \%$ & $91 \%$ & $17 \%$ & $91 \%$ & $91 \%$ \\
\hline $\begin{array}{l}\text { Random } \\
\text { Forest }\end{array}$ & $91 \%$ & $99 \%$ & $79 \%$ & $98 \%$ & $98 \%$ \\
\hline $\begin{array}{l}\text { Support } \\
\text { Vector } \\
\text { Machine } \\
\text { (SVM) }\end{array}$ & $93 \%$ & $100 \%$ & $25 \%$ & $93 \%$ & $96 \%$ \\
\hline $\begin{array}{l}* \text { Neural } \\
\text { Network }\end{array}$ & $97 \%$ & $99 \%$ & $79 \%$ & $98 \%$ & $98 \%$ \\
\hline
\end{tabular}

Berdasarkan hasil dari Tabel performance ada 5 pilihan:

- Pilih algoritma yang memiliki accuracy tinggi jika yang dipentingkan adalah seberapa akurat sistem mengklasifikasi dengan benar, accuracy merupakan rasio prediksi benar (positif dan negatif) dengan keseluruhan data. Dari Tabel terlihat algoritma yang memiliki akurasi tertinggi adalah neural network disusul oleh svm dan random forest.

- Pilih algoritma yang memiliki recall tinggi jika, pengambil keputusan lebih memilih False Positive terjadi daripada False Negative Dalam penelitian ini, lebih baik algoritma salah memprediksi lokasi bagus tetapi sebenarnya buruk, daripada algoritma salah memprediksi bahwa lokasinya buruk padahal sebenarnya bagus.

- Pilih algoritma yang memiliki precission tinggi jika, pengambil keputusan lebih menginginkan terjadinya True Positive dan sangat tidak menginginkan terjadinya False Positive Pada penelitian ini lebih baik algoritma salah memprediksi lokasi buruk padahal sebenarnya bagus daripada salah memprediksi lokasi baik padahal sebenarnya buruk.

- Pilih algoritma yang memiliki specificity tinggi jika, pengambil keputusan tidak menginginkan terjadinya false positif. Sistem sangat mengharapkan tidak terjadi salah mendeteksi lokasi yang sebenarnya buruk tapi diprediksi bagus

- Pilih algoritma dengan F1 Score tertinggi jika, pengambil keputusan lebih mementingkan recall dan precision yang tinggi. Artinya yang dipilih adalah algoritma yang memberikan nilai False Positive kecil dan False Negative kecil juga. 
Dari kelima pengukuran evaluasion matrix di atas, bagi peritel algoritma yang dipilih adalah algoritma yang memiliki F1 Score tertinggi, yaitu algoritma yang memiliki false positive paling sedikit dan false negative sedikit. Sehingga peritel memiliki resiko mengalami kerugian yang kecil (false positive rendah) dan memiliki resiko kehilangan keuntungan yang kecil (false negative rendah). Dari Tabel di atas sistem yang memiliki F1 Score yang tinggi $98 \%$, adalah algoritma neural network, random forest atau svm. Selain algoritma yang memiliki F1 Score tertinggi, bisa juga dipilih algoritma yang memiliki false positive paling sedikit yaitu algoritma yang memiliki nilai precision tinggi seperti neural network, svm dan random forest.

\section{B. Kurva $R O C$ dan $A U C$}

Pada Confusion matrix, performa informasi hanya disajikan dalam bentuk angka. Untuk menampilkan informasi kinerja algoritma klasifikasi dalam bentuk grafik dapat digunakan Receiver Operating Characteristic (ROC) atau Precision-Recall Curve.

Kurva $R O C$ dibuat berdasarkan nilai yang telah didapatkan dari perhitungan dengan confusion matrix, yaitu antara False Positive Rate dengan True Positive Rate. Untuk membandingkan nilai kinerja masing-masing algoritma dapat dilakukan dengan membandingkan luas di bawah kurva atau AUC (Area Under Curve).

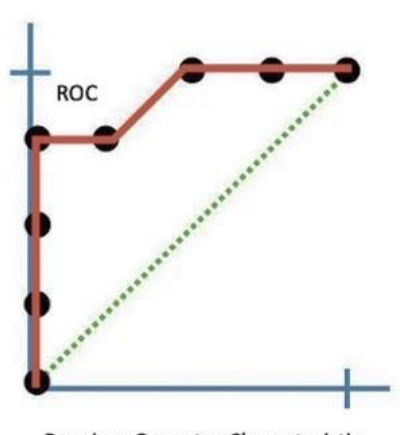

Receiver Operator Characteristic

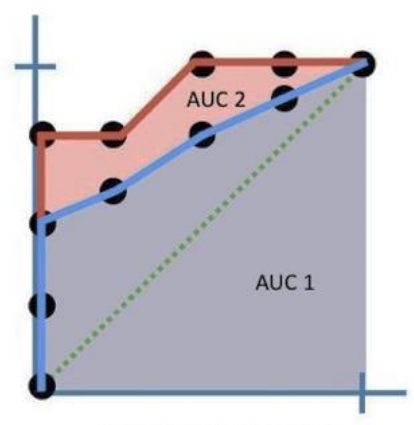

Kurva Area Under Curve
Gambar 10. Kurva ROC dan AUC [11]

Kelebihan dari penggunaan kurva ROC untuk mengevaluasi klasifikasi adalah $R O C$ bukan sekedar untuk mencari rata-rata akurasi tetapi $R O C$ memvisualisasikan semua threshold klasifikasi yang mungkin, sedangkan error rate classifier hanya mewakili tingkat kesalahan, akurasi untuk satu threshold saja [11].

Berikut adalah hasil dari pengujian dari 6 Algorima klasifikasi.

A. Hasil Confusion Matrix dan Kurva ROC dan AUC Logistic Regression.

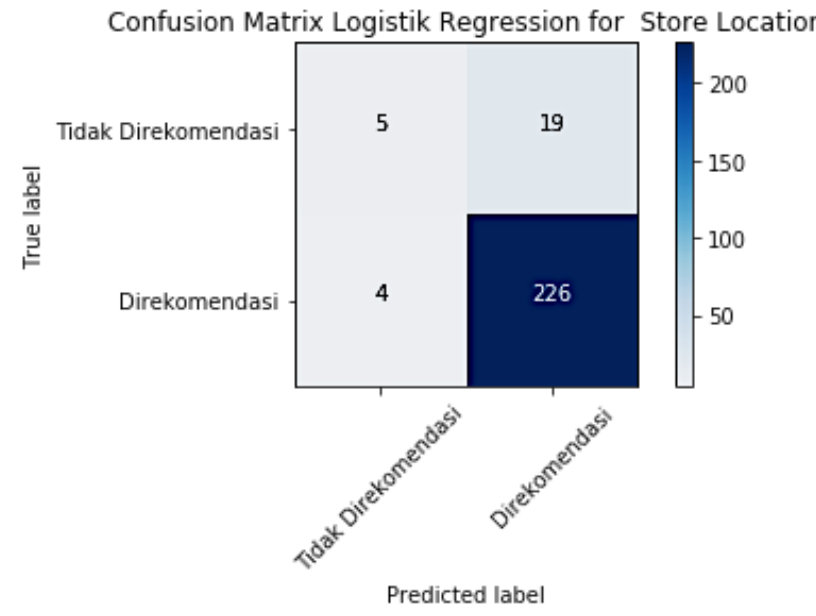

True Positives: 226

True Negatives: 5

False Positives: 19

False Negatives: 4

Accuracy: 0.91

Sensitivity: 0.98

Specificity: 0.21

Precision: 0.92

f_1 Score: 0.95

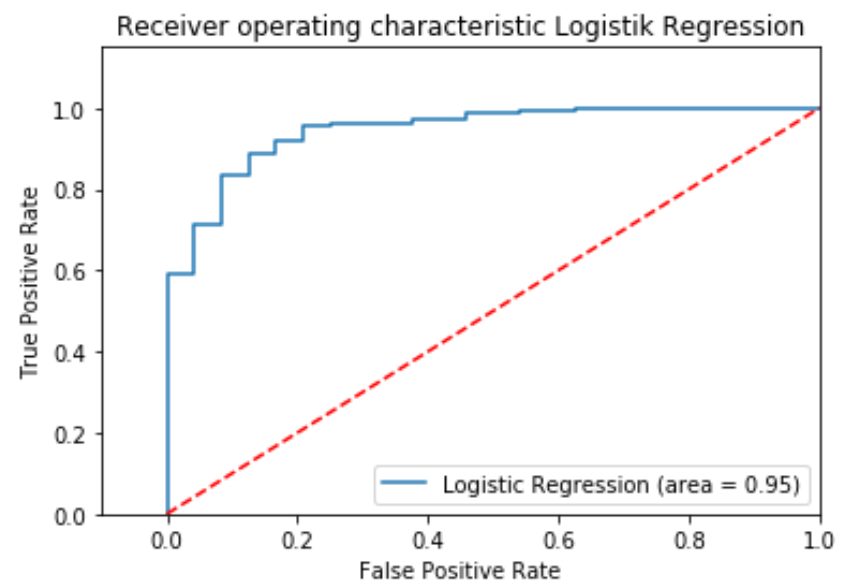

Gambar 11. Confusion Matrix dan kurva ROC-AUC Logistic Regression.

Berdasarkan pada Gambar 12, hasil pengujian di atas, menunjukan bahwa akurasi logistic regression sebesar $91 \%$ dan $A U C$ sebesar 0.95 .

B. Hasil Confusion Matrix dan Kurva ROC dan AUC KNearest Neigbor $(K N N)$ 

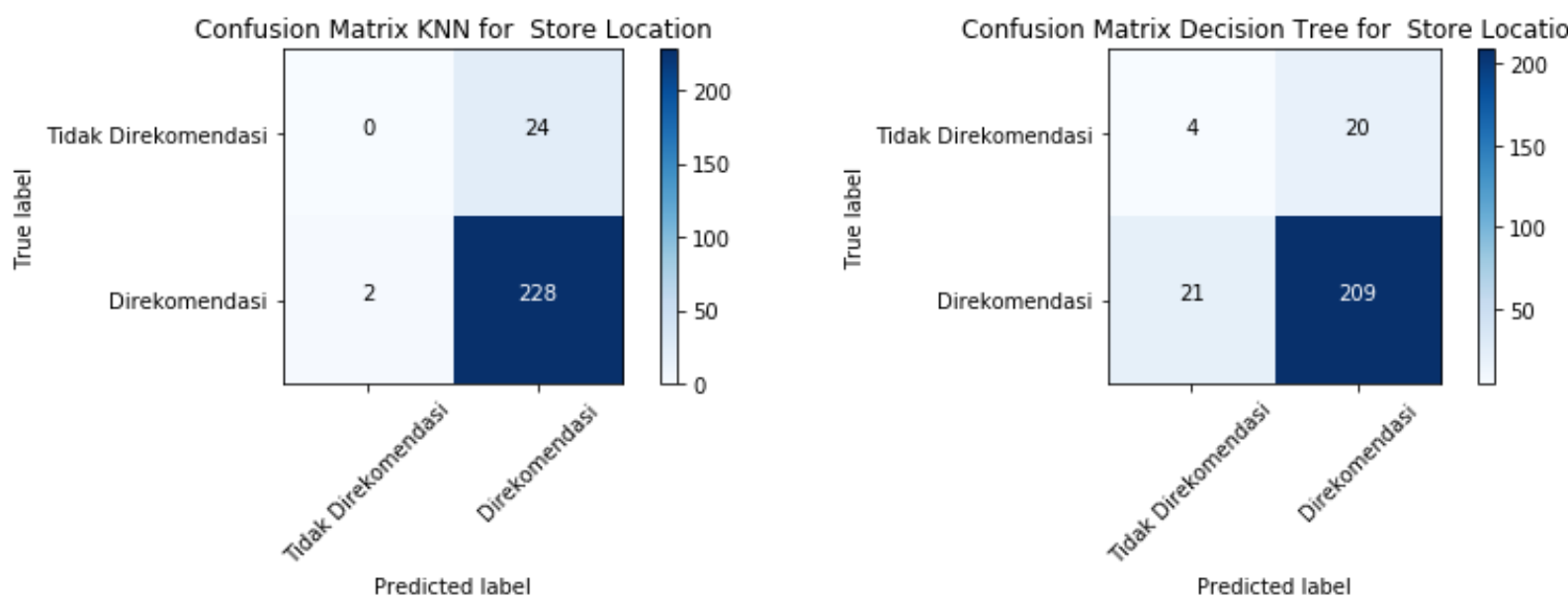

True Positives: 228

True Negatives: 0

False Positives: 24

False Negatives: 2

\section{Accuracy: 0.9}

Sensitivity: 0.99

Specificity: 0.0

Precision: 0.9

f 1 Score: 0.95

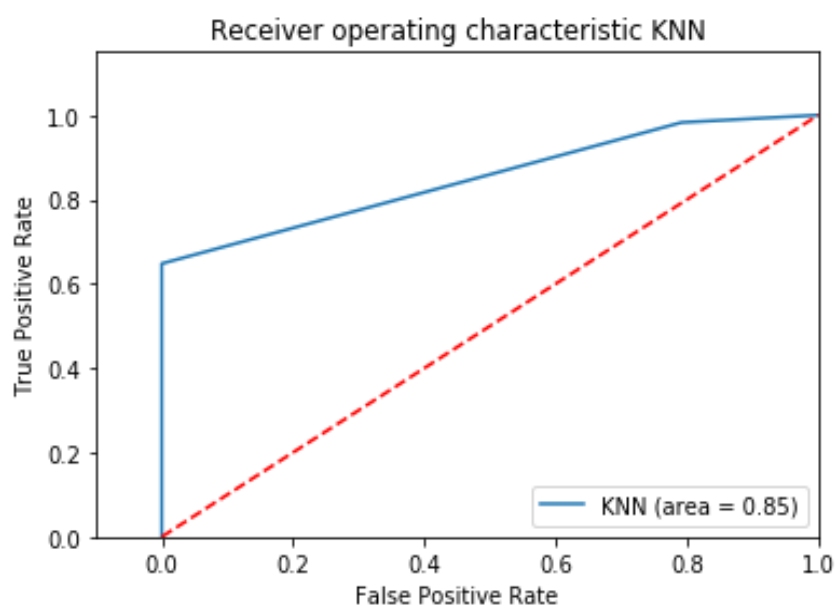

Gambar 12. Confusion Matrix dan kurva ROC-AUC KNN

True Positives: 209

True Negatives: 4

False Positives: 20

False Negatives: 21

Accuracy: 0.84

Sensitivity: 0.91

Specificity: 0.17

Precision: 0.91

f 1 Score: 0.91

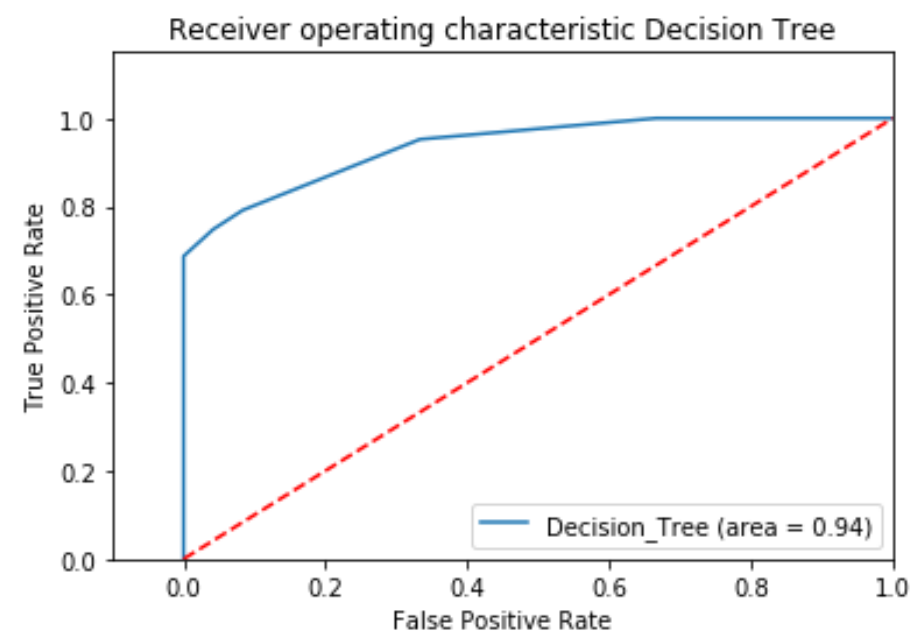

Gambar 13. Confusion Matrix dan kurva ROC-AUC Decision Tree

Berdasarkan pada Gambar 13, hasil pengujian di atas, menunjukan bahwa akurasi model KNN sebesar 90\% dan AUC sebesar 0.85 .

Berdasarkan pada Gambar 14, hasil pengujian di atas, menunjukan bahwa akurasi model Decision Tree sebesar 84\% dan AUC sebesar 0.94 .

D. Hasil Confusion Matrix dan Kurva ROC dan $A U C$ Random Forest. 


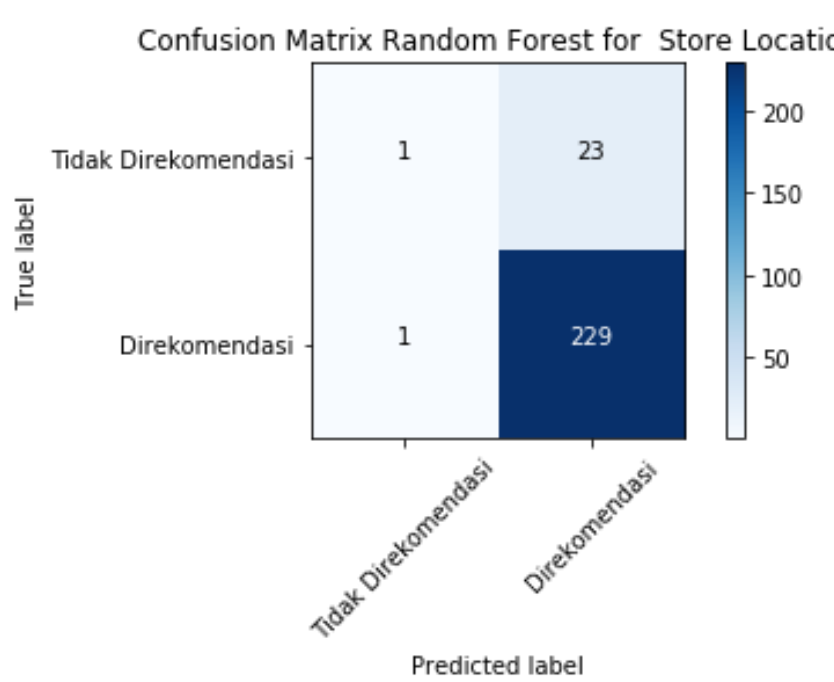

True Positives: 229

True Negatives: 1

False Positives: 23

False Negatives: 1

Accuracy: 0.91

Sensitivity: 1.0

Specificity: 0.04

Precision: 0.91

f 1 Score: 0.95

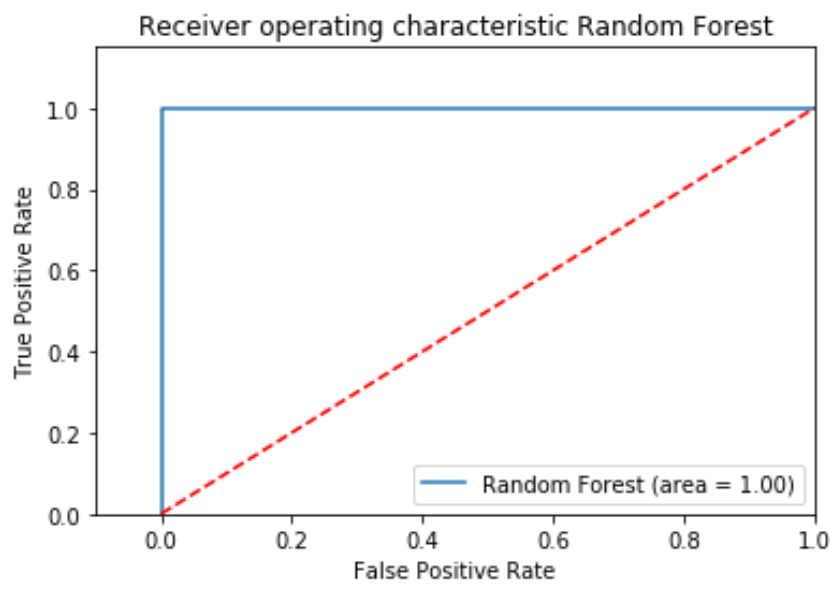

Gambar 14. Confusion Matrix dan kurva ROC-AUC Random Forest dengan $n \_$estimators $=100$

Berdasarkan pada gambar 14, hasil pengujian di atas, menunjukan bahwa akurasi model Random Forest sebesar 91\% dan AUC sebesar 1.

$A U C=1$ artinya hasil True Positive Rate selalu angka 1 berapapun nilai False Positive Ratenya. Maka artinya Pengklasifikasian Random Forest dapat dengan sempurna membedakan antara semua poin kelas Positif dan Negatif dengan benar. Semakin tinggi $A U C$, semakin baik kinerja model dalam membedakan kelas positif dan negatif. Random
Forest mendapatkan $A U C=1$, karena parameter $n \_$estimators diset cukup tinggi 100, n_estimators menunjukkan jumlah pohon yang digunakan, semakin tinggi nilai $n \_$estimators akan memberikan nilai akurasi dan nilai dari kurva $A U C$ yang semakin baik tetapi nilai $n \_$estimators yang tinggi akan memperlambat proses perhitungan.

Sebagai perbandingan Gambar 15 adalah kurva AUC untuk $n \_$estimators $=3$, dengan $n \_$estimators $=3$ nilai kurva AUC turun menjadi 0.97

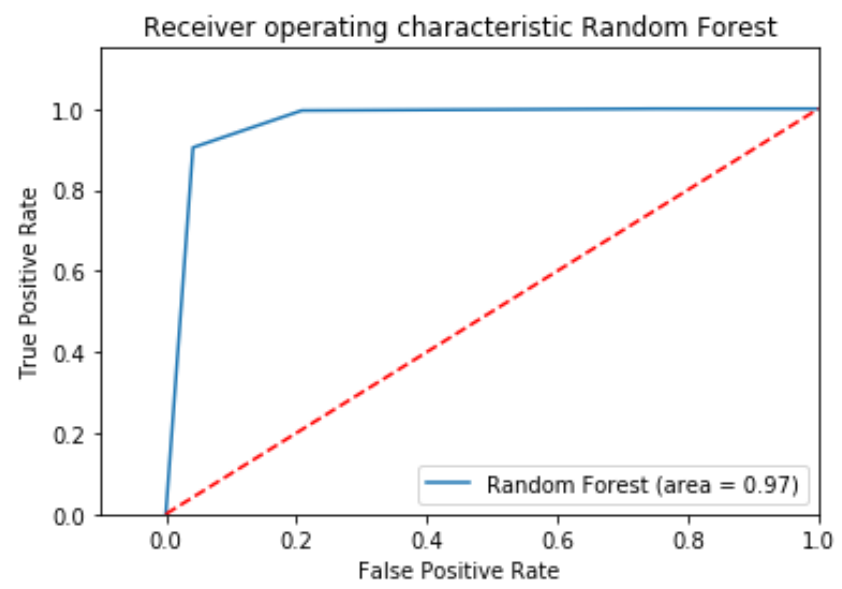

Gambar 15. Confusion Matrix dan kurva ROC-AUC Random Forest dengan $n \_$estimaotors $=3$

E. Hasil Confusion Matrix dan Kurva ROC dan AUC Support Vector Machine (SVM).

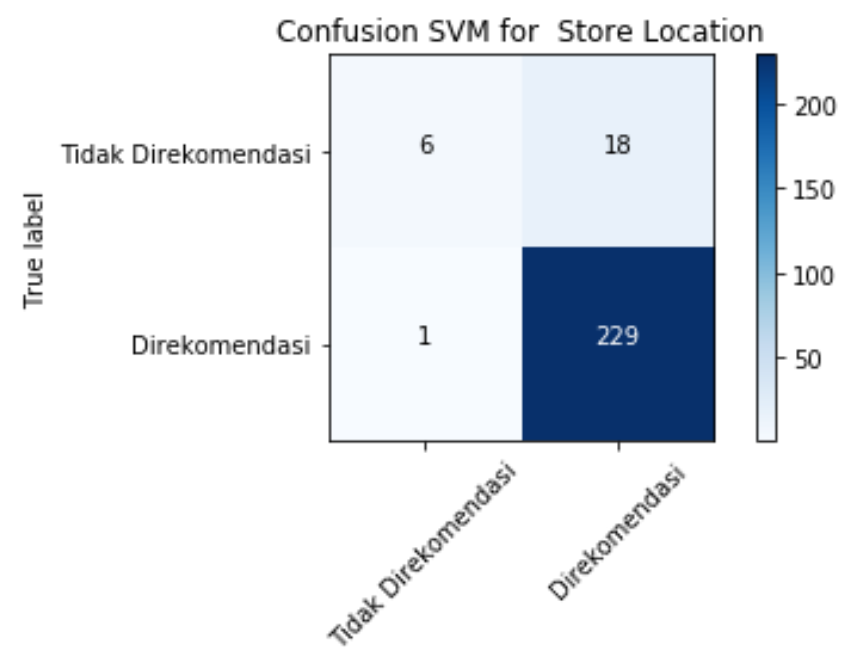

Predicted label

True Positives: 229

True Negatives: 6

False Positives: 18

False Negatives: 1

Accuracy: 0.93 
Sensitivity: 1.0

Specificity: 0.25

Precision: 0.93

f 1 Score: 0.96

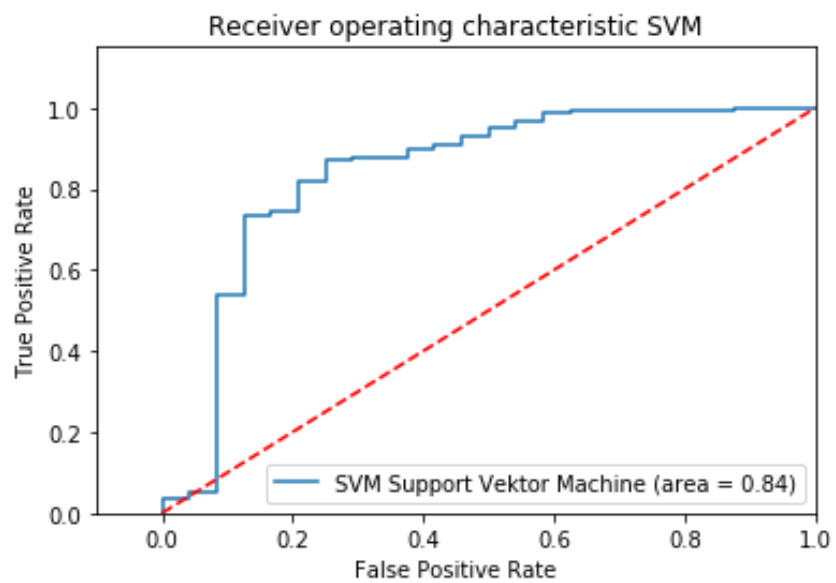

Gambar 16. Confusion Matrix dan kurva ROC-AUC SVM

Berdasarkan pada Gambar 16, menunjukan bahwa akurasi Support Vector Machine (SVM) sebesar 93\% dan AUC sebesar 0.84 .

F. Hasil Confusion Matrix dan Kurva ROC dan $A U C$ Neural Network.

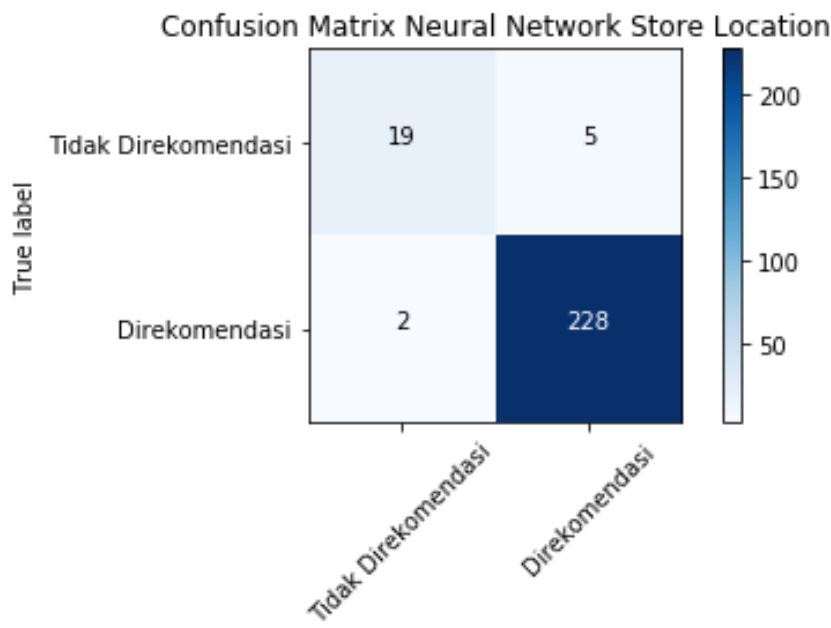

Predicted label

True Positives: 228

True Negatives: 19

False Positives: 5

False Negatives: 2

Accuracy: 0.97
Sensitivity: 0.99

Specificity: 0.79

Precision: 0.98

f_1 Score: 0.98

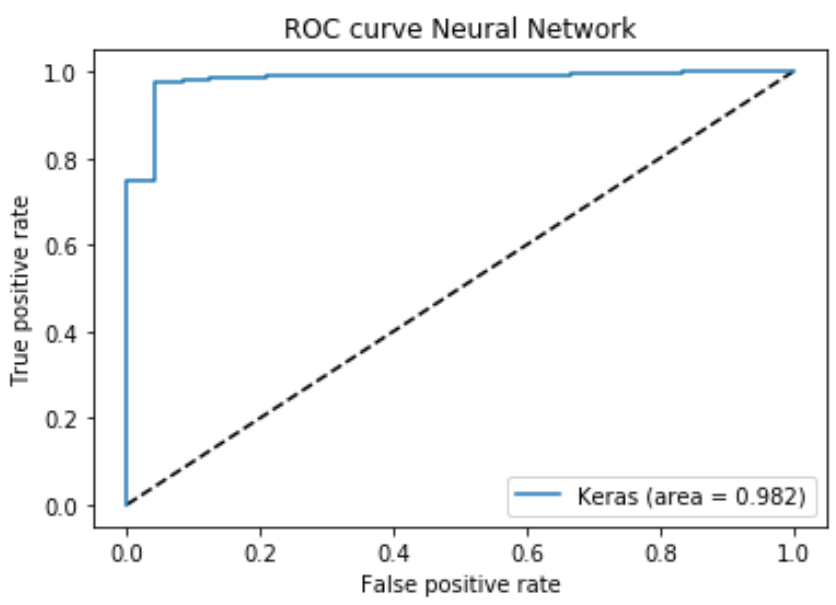

Gambar 17. Confusion Matrix dan kurva ROC-AUC Neural Network Berdasarkan pada Gambar 17, menunjukan bahwa akurasi Neural Network sebesar $94 \%$ dan AUC sebesar 0.97 .

Dari hasil evaluasi keenam algortma tersebut didapat Tabel perbandingan seperti di bawah ini.

TABEL II

PERBANDINGAN Hasil Evaluasi

\begin{tabular}{|l|l|l|l|}
\hline Algoritma & $\begin{array}{l}\text { Accuracy } \\
\text { Conf. Matrix }\end{array}$ & AUC & $\begin{array}{l}\text { False } \\
\text { Positive }\end{array}$ \\
\hline $\begin{array}{l}\text { Logistic } \\
\text { Regression }\end{array}$ & $91 \%$ & 0.95 & 19 \\
\hline $\begin{array}{l}\text { K Nearest } \\
\text { Neighbor (KNN) }\end{array}$ & $90 \%$ & 0.85 & 24 \\
\hline Decision Tree & $84 \%$ & 0.94 & 20 \\
\hline Random Forest & $91 \%$ & 1 & 23 \\
\hline $\begin{array}{l}\text { Support Vector } \\
\text { Machine (SVM) }\end{array}$ & $93 \%$ & 0,84 & 18 \\
\hline Neural Network & $97 \%$ & 0.98 & 5 \\
\hline
\end{tabular}

\section{SIMPULAN}

Dalam Penelitian ini telah dilakukan penelitian menggunakan data lokasi toko untuk membuat model rekomendasi biner (binary classification) untuk lokasi toko baru, menggunakan metode klasifikasi dari 6 algoritma yang berbeda yaitu Logistic Regression, K-Nearest Neighbor (KNN), Decision Tree, Random Forest, Support Vector Machine (SVM) dan Neural Network. 
Berdasarkan hasil evaluasi didapatkan algoritma neural network memiliki akurasi paling baik yaitu sebesar 97\%, disusul algoritma SVM sebesar 93\%, kemudian diikuti oleh algoritma logistic regression dan random forest sebesar $91 \%$, lalu algoritma $K N N$ sebesar $90 \%$ dan yang terakhir decision tree sebesar $84 \%$. Nilai $97 \%$ menunjukkan bahwa ketepatan model neural network dalam memprediksi satu lokasi direkomendasi atau atau tidak dari total 254 prediksi hanya 7 prediksi yang salah.

Sementara jika dilihat dari kurva $R O C$ dan $A U C$ yang terbaik adalah algoritma Random Forest sebesar 1, disusul oleh Neural Network sebesar 0.97, disusul oleh Logistic Regression sebesar 0.95, lalu diikuti oleh Decision Tree 0.94, setelahnya $K N N$ sebesar 0.85 dan terakhir adalah SVM $0.84 \%$.

Penelitian uji diagnostic akan semakin baik bila nilai AUC mendekati 1._Nilai AUC: $0.5 \leq \mathrm{AUC}<0.6$ sangat lemah, $0.6 \leq \mathrm{AUC}<0.7$ lemah, $0.7 \leq \mathrm{AUC}<0.8$ sedang, $0.8 \leq$ AUC $<0.9$ baik dan $0.9 \leq$ AUC $\leq 1$ sangat baik.

Jadi jika berdasarkan hasil evaluasi, kurva ROC-AUC, model terbaik adalah Neural Network lalu logistic regression.

Nilai AUC memberikan gambaran tentang keseluruhan perngukuran atas kesesuaian dari model yang digunakan. Semakin besar Area Under Curve (AUC) maka semakin baik model dalam memprediksi lokasi.

Dari sisi bisnis memilih lokasi yang tepat berdasarkan akurasi dan ROC-AUC memang penting, tetapi menghindari pemilihan lokasi yang salah (false positive) juga penting bahkan lebih penting, maka dari itu, nilai dari false positive pada confusion matrix sangat penting untuk juga diperhatikan. Nilai false positive penting karena nilai tersebut menunjukkan seberapa banyak sistem melakukan kesalahan dalam memilih lokasi, memprediksi bahwa lokasi tersebut baik padahal kenyataannya buruk. Dibandingkan dengan nilai fales negative, False positive jauh lebih penting karena jika satu lokasi diprediksi buruk padahal kenyataannya baik (false negative) perusahaan hanya kehilangan kesempatan untuk untung tetapi secara keuangan tidak dirugikan, sebaliknya jika satu lokasi diprediksi bagus padahal kenyataan jelek, maka perusahaan akan mengalami kerugian yang cukup besar bahkan bisa mengganggu keuangan keseluruhan perusahaan.

Berdasarkan hasil evaluasi algoritma yang memiliki nilai false positive paling kecil adalah neural network yaitu 5, nilainya jauh lebih kecil jika dibandingkan dengan hasil alogritma dari algoritma lainnya. Tapi jika peritel ingin tidak mengalami kerugian dan tidak ingin kehilangan keutungan maka algoritma yang harus dipilih adalah algoritma yang memiliki F1 Score tertinggi. Dari Tabel performance terlihat bahwa sistem yang memiliki F1 Score tertinggi adalah neural network dan random forest.

Jadi jika disimpulkan neural network adalah pilihan terbaik untuk pemilihan toko disusul oleh random forest, SVM dan terakhir logistik regression.

Untuk keperluan penelitan lebih lanjut agar supaya mendapatkan nilai akurasi yang lebih baik maka diusulkan untuk mencoba menggunakan algoritma-algoritma lain seperti Deep Learning, menambahkan jumlah data training serta menambah fitur-fitur lain seperti pendapatan penduduk di daerah tersebut, jumlah keluarga, fasilitas parkir dan lainlain.

\section{DAFTAR PUSTAKA}

[1] K. Dolan, "Forbes.com," [Online]. Available: https://www.forbes.com/sites/kerryadolan/2020/12/17/billion-dollardynasties-these-are-the-richest-families-inamerica/?sh=600339da772c.. [Accessed 1 December 2020].

[2] I. Rish, "An Empirical Study of the Naive Bayes Classifier," in IJCAI 2001 Workshop on Empirical Methods in Artificial Intelligence, IBM, Vol 3, New York, 2001.

[3] Diana, "Sistem Pendukung Keputusan Menentukan Lokasi Usaha Waralaba Menggunakan Metode Bayes.," Jurnal Ilmiah MATRIK , vol. 19, 2017.

[4] J. Brownlee, Master Machine Learning Algorithms, Melbourne, 2017.

[5] D. Solyali, "A Comparative Analysis of Machine Learning Approaches for Short-/Long-Term Electricity Load Forecasting in Cyprus," Sustainability, vol. 12, 2020.

[6] J. Ali, R. Khan, N. Ahmad and I. Maq, "Random Forests and Decision Trees," IJCSI International Journal of Computer Science Issues, vol. 9, no. 5, 12 May 2012.

[7] C. V. L. M. Premalatha, "SVM Trade-Off Between Maximize the Margin and Minimize the Variables Used for Regression," International Journal of Pure and Applied Mathematics, vol. 87 , no. 6, December 2013.

[8] B. N. S. C. S. K. S. Harsh Kukreja, "An Introduction to Artificial Neural Network," International Journal Of Advance Research And Innovative Ideas In Education, vol. 1, no. 5, April 2016.

[9] A. E. Isabelle Guyon, "An Introduction to Variable and Feature Selection," Journal of Machine Learning Research 3, vol. 11, no. 2, p. 26, November 2003.

[10] D. Berrar, "Cross Validation," Tokyo Institute of Technology, Tokyo, Japan, November 2018.

[11] C. G. Gaussier, "A Probabilistic Interpretation of Precision, Recall and F-Score, with Implication for Evaluation," European Conference on Information Retrieval Advances in Information Retrieval, vol. 3408, pp. 345-359, June 2005. 